\title{
Osama bin Ladens slagkraft
}

Osama bin Ladens uttalelser vekker ofte gjenkjennelse, og de gjør seg derfor gjeldende. Tekstene hans er tilpasset et bredt publikum, og det er noe av årsaken til at han ikke bare anses som en terrorist, men også som en leder, heltefigur og frihetskjemper. I denne artikkelen skal det handle om bin Ladens retoriske slagkraft og makt. 
TEKST: Anne Birgitta Nilsen

OSAMA BIN LADENS MAKT kan virke både uforståelig og ubegripelig. Hvorfor oppfattes denne mannen som en frihetskjemper og en helt blant en del mennesker? Og hvorfor får akkurat han så mye oppmerksomhet i mediene? I denne artikkelen skal jeg forsøke å gi noen svar på disse spørsmålene, men som verdens mest ettersøkte mann er informasjon om bin Laden vanskelig tilgjengelig. Tekstene hans og medienes fremstillinger av ham er blant de få kildene vi har til kunnskap om hans maktutøvelse. For å belyse bin Ladens makt skal jeg derfor både presentere en analyse av det panarabiske nyhetsmediet al-Jazeera sin visuelle fremstilling av bin Laden og retoriske analyser fra hans tekster.

\section{Osama bin Ladens engasjement}

Mange forbinder hovedsakelig bin Laden med terrorisme og den spesielle formen for islam som han forsøker å spre verden over. Det er imidlertid ikke først og fremst for sin religiøse innsikt bin Laden tekkes mange av sine tilhørere, men for sine politiske evner. Det er derfor ikke hans fortolkning av islam som gjør at han tiltrekker seg mye oppmerksomhet, slik mange ser ut til å tro. Denne fortolkningen er nok for de færreste. De langt fleste tar også avstand fra mange av metodene og volden som benyttes av al-Qaida og den type sharia-styre de går inn for, men for tiden utgjør dette mindre viktige detaljer. Det er ikke det saken dreier seg om akkurat nå. Etter århundrer med opplevelser av forfall, ydmykelser, utnytting og utbytting ser mange på bin Laden som en person som har brakt dem håp og verdighet. Når den panarabiske Qatar-baserte kanalen alJazeera sender en video eller et lydbåndopptak med ham eller et dokumentar-program om ham, benker folk seg foran fjernsynet for å se og høre denne mytiske heltefiguren.

Det mange beundrer bin Laden for, er de politiske sakene han fremmer og synliggjør. Mye av hans popularitet stammer trolig fra hans sosiale og politiske engasjement. Hamid Mir, forfatteren av bin Ladens pakistanske biografi, sier at bin Laden er en flink politiker, men at han er mindre overbevisende når det kommer til religion. ${ }^{2}$ I forbindelse med karikatursaken i 2006 sa bin Laden for eksempel:

En måte å se ned på folk og vise forakt for dem på, er først å gjøre narr av det de holder hellig, for deretter à utvise solidaritet med dem som føler seg sjikanert og så invitere til dialog og ro. En annen måte å latterliggjøre og håne folk på, er å la fly og bomber rasere husene over hodene 
på våre familier og våre barn i Palestina og Irak, Afghanistan, Tsjetsjenia og Pakistan, for deretter å smile oss rett opp $i$ ansiktet og si: Vi angriper ikke islam, vi angriper terroristene.

I forbindelse med utgivelsen av bin Ladens taler på norsk sa foreleggeren, Frode Saugstad, at dersom man ser bort fra de grusomme terrorhandlingene til al-Qaida, så kan kanskje mange bli overrasket over at bin Laden fremstår som en slags humanistisk terrorist. ${ }^{4}$ Slik jeg ser det, er bin Ladens karisma trolig det viktigste for forståelsen av hans popularitet, og de viktigste faktorene her er veltalenhet og makt - sider av bin Laden som er nærmest helt fraværende i vestlige medier, men ganske tydelige i det panarabiske nyhetsmediet, al-Jazeera.

\section{Bin Laden på al-Jazeera}

Tekstene til bin Laden har inntil nylig vært publisert på al-Jazeera sin tv-kanal og nettsider. Det er altså ikke bare opp til bin Laden selv hvordan han opptrer og fremstår. Mediene der han fremstilles, spiller også en sentral rolle, og han er i sin isolasjon, hvor hen han måtte befinne seg, helt avhengig av mediene. Al-Jazeera er en av de største panarabiske tv-kanalene og har, som nevnt, sendt mange av talene hans. Mediet har derfor, særlig fra vestlig hold, vært beskyldt for å ha forbindelser til alQaida og fungere som deres talerør. Denne forbindelsen var frem til mai 2008 en av alJazeeras kameramenn, Sami al-Hajj. Etter syv år på Guantanamo ble han imidlertid satt fri uten at det var blitt reist tiltale mot ham. Forklaringen på hvorfor al-Jazeera har sendt og trykket tekstene til bin Laden, er derfor ikke lenger styrket av al-Hajj sin påståtte forbindelse til al-Qaida. Det er dessuten heller ikke slik at det bare er mediene som skaper diskursene de jobber med. Media både formes av og reflekterer holdninger innenfor et bredere kulturelt miljø. Her dreier det seg om en form for samspill innenfor en bredere kulturkontekst der også al-Jazeera sitt publikum spiller en vesentlig rolle, for mediene er også avhengige av sitt publikums interesser og oppfatninger.

På al-Jazeera sine nettsider er det en kollasj på forsiden til Osama bin Laden og Ayman al-Zawahiri sine taler, 5 og kollasjer er ganske vanlige i al-Jazeera sitt bakgrunnsstoff. Her kan man kan enten klikke på bin Laden eller al-Zawahiri avhengig av hvilke taler man vil lese. Kollasjen har portretter av de to lederne i forgrunnen og et animert bilde fra II.september 200I i bakgrunnen.

Fremstillingen er trolig ganske representativ for hvordan bin Laden og alZawahiri oppfattes blant mange mennesker i dag. Her er de medierte som helter, og dette er en fremstilling mange gjenkjenner. Fokuset ligger på operasjonens bakmenn eller heltene bak aksjonen da disse er plassert i forgrunnen, nærmest leseren. Angrepet på tvillingtårnene foregår i bakgrunnen, og bildet antyder bare hva som foregår, fordi det er tatt på lang avstand. Terroren, redselen, frykten og drapene er ikke synlig, bare de to mennene kledd i hvitt - renhetens, uskyldens og fredens farge. Kollasjen synes gjennom de hvite klærne å antyde alZawahiri og bin Ladens uskyld og renhet, uten at dette sies eksplisitt. Det kan være et forsøk på å skape en forbindelse til noe som allerede finnes hos leserne, for at bin Laden er uskyldig, er ingen uvanlig oppfatning. Kollasjen kan bidra til å bekrefte og forsterke forestillingen og oppfatningen av bin Laden og al-Zawahiri som helter og fri- 
hetskjempere. På den måten er den et eksempel på at også bilder, på samme måte som tekst, kan skape uttrykk og overbevisning.

De utvalgte elementene i kollasjen, de to mennene og tvillingtårnene, peker tilbake til de ulike paradigmene de er hentet fra. De illustrerer på den måten noe generelt ved å vise noe konkret: Handelstårnene på den ene siden representerer kapitalisme og økonomisk makt og det amerikanske, kanskje også det vestlige for noen. De to mennene representerer motstanden mot alt tvillingtårnene står for. Kollasjen kan beskrives som en type visuell retorikk som representerer en fastholdelses- og fellesskapsstrategi. ${ }^{6}$ Makten i denne formen for retorikk ligger $i$ at den styrker bestemte holdninger, synspunkter eller verdier hos mottakerne, og på den måten virker den samlende. ${ }^{7}$

\section{Bin Laden i vestlige medier}

Bildet av bin Laden i vestlige medier ser ganske annerledes ut, og flere har påpekt at han ikke har den samme slagkraften i Vesten. Peter Bergen, en ekspert på bin Laden, sier at bin Laden ikke forstår USA. ${ }^{8}$ Daniel Benjamin ved Senter for strategiske og internasjonale studier i Washington, sier at han ikke tror bin Laden har noen innflytelse i Vesten. ${ }^{9}$ Det er trolig riktig slik Benjamin og Bergen sier, og det har antakeligvis sin bakgrunn i to forhold: For det første slipper bin Laden i liten grad til i vestlige medier. I følge Tareq $\mathrm{Ali}^{\text {io }}$ er grunnen til dette at bin Ladens milde trekk undergraver medienes portrett av ham som inkarnasjonen av ondskap. I norske medier blir bin Laden som oftest bare referert med løsrevne sitater fra talene sine. Dette er sitater som inneholder oversettelsesfeil og som ofte er trukket ut av sin sammenheng. De gjenspeiler trolig både oversetternes og journalistenes negative holdning overfor bin Laden, samt en tvilsom forståelse av jihad-retorikken som sjanger. Det er med andre ord i svært i liten grad gjort forsøk på å anskueliggjøre bin Ladens talegaver.

\section{"Dere har forsøkt å hindre oss $i \stackrel{a}{ }$ leve et verdig liv, men dere kan ikke} hindre oss i à dø en verdig død."

Snarere fremstår han som en bakstreversk leder med et språk som ikke er egnet for en moderne verden, langt mindre for å overtale og overbevise. ${ }^{\text {II }}$ Den andre årsaken til at bin Laden i liten grad har innflytelse i Vesten, er at han ikke befester sin posisjon som en politisk leder gjennom sin retorikk og fremtreden. Temaene og virkemidlene i talene er tilpasset et annet publikum, og de nøye redigerte talene slår ikke an her. Flere journalister har kommentert hans opplesninger og beskrevet dem som monotone og kjedelige, at han ser ut som en nyhetsoppleser og at han prosodisk sett er slående i sin mangel på kunstferdighet. Det kan så være at uttrykkssiden kan oppfattes som kjedelig, men tekstene har også en innholdsside. Bin Laden fremviser for eksempel en språklig kreativitet, som særlig kommer til uttrykk når han utbroderer sine fiendebilder og utnytter satire og kjente historiske symboler. I en tekst fra desember 2004 sier han for eksempel at:

La dem vite at det er ingen forskjell mellom å godkjenne valget av den første Abu Jahl, Amr bin Hisham, og å velge Abu Jahl Iyad Allawi, 
Abu Jahl Mahmoud Abbas og Abu Jahl Fahd bin Abd al-Aziz. ${ }^{12}$

I dette sitatet sidestilles en del av samtidens politiske ledere med Abu Jahl (uvitenhetens far), for Abu Jahl var på Profeten Muhammads tid kjent som en hard motstander mot islam. Abu Jahl refererer til en historisk skikkelse som er velkjent fra islams historie og er et symbol på hedningene og de uvitende. Det satiriske ved begrepet jahl (uvitenhet) ligger særlig i dets konnotasjoner til dumskap og tåpelighet.

\section{Bin Laden hater ikke vestlig frihet}

Det synes å herske en utbredt misforståelse, og den går ut på at bin Laden misliker Vesten og særlig USA på grunn av friheten som råder. Denne misforståelsen kan spores tilbake til president George W. Bush, for han har flere ganger hevdet at det er friheten vår de hater. Under en videokonferanse i 200I sa presidenten for eksempel at "vi har innledet en ny type krig. Det er en krig mot folk som hater frihet." I en tale samme år sa han at "de hater vår frihet, vår frihet til å samles og være uenige med hverandre og vår frihet til å stemme ved politiske valg. ” ${ }^{\text {13 }}$ De fleste har nå fått med seg at det snarere er på grunn av dens synder at den vestlige verden vekker negative følelser, og ikke på grunn av dens dyder.

En misnøye og et hat overfor Vesten er et gjennomgående tema i Osama bin Laden sine taler, og han har gjentatte ganger forsøkt å oppklare denne misforståelsen, eller det han mener er et forsøk på å forvirre og villede folk. I oktober 2004 sa han for eksempel at:

Dere forbløffer meg imidlertid, for selv om det har gått mer enn tre år siden hendelsene den
11. september, fortsetter Bush å forvirre og villede dere, samt å holde den egentlige årsaken skjult for dere. ${ }^{14}$

Innledningsvis i samme tale sa han:

Amerikas folk, nå vil jeg snakke til dere om den beste måten å unngå et nytt Manhattan på, og om krigen og dens årsaker og konsekvenser. Først vil jeg si dere at sikkerhet er en av grunnpilarene for menneskelig liv. Frie mennesker gir ikke avkall på sin sikkerhet, selv om Bush påstår at vi hater frihet. Han kan kanskje fortelle oss hvorfor vi ikke har angrepet for eksempel Sverige? ${ }^{25}$

Her refererer trolig bin Laden til at Sverige aldri har vært noen angriper i den muslimske verden, og svenskene blir derfor heller ikke angrepet til tross for at det hersker stor grad av frihet $\mathrm{i}$ landet.

Det er altså ikke et hat overfor frihet som preger talene til bin Laden. Hans prosjekt er å synliggjøre en krig han mener pågår mot muslimene, og han oppfordrer folk til motstand og forsvar. I sine taler forsøker bin Laden derfor så godt han kan å nøre opp under negative følelser overfor Vesten, og han benytter det som et virkemiddel for å overbevise og overtale folk til jihad. Slikt sett kan vi grovt dele hans publikum inn i to grupper. Den ene gruppen består av dem han forsøker å overbevise om at motstand er nødvendig og at jihad er den rette veien å gå. Den andre gruppen består av dem som allerede er overbeviste og som han forsøker å overtale til å handle.

Bin Laden fokuserer på de dårlige forholdene mange muslimer lever under og kobler disse til Vestens og særlig USAs

Osama bin Laden står som oftest frem i hvite klær. 
babylon 12 : babylon $5 \quad 30-09-08 \quad 10: 33$ Side 43

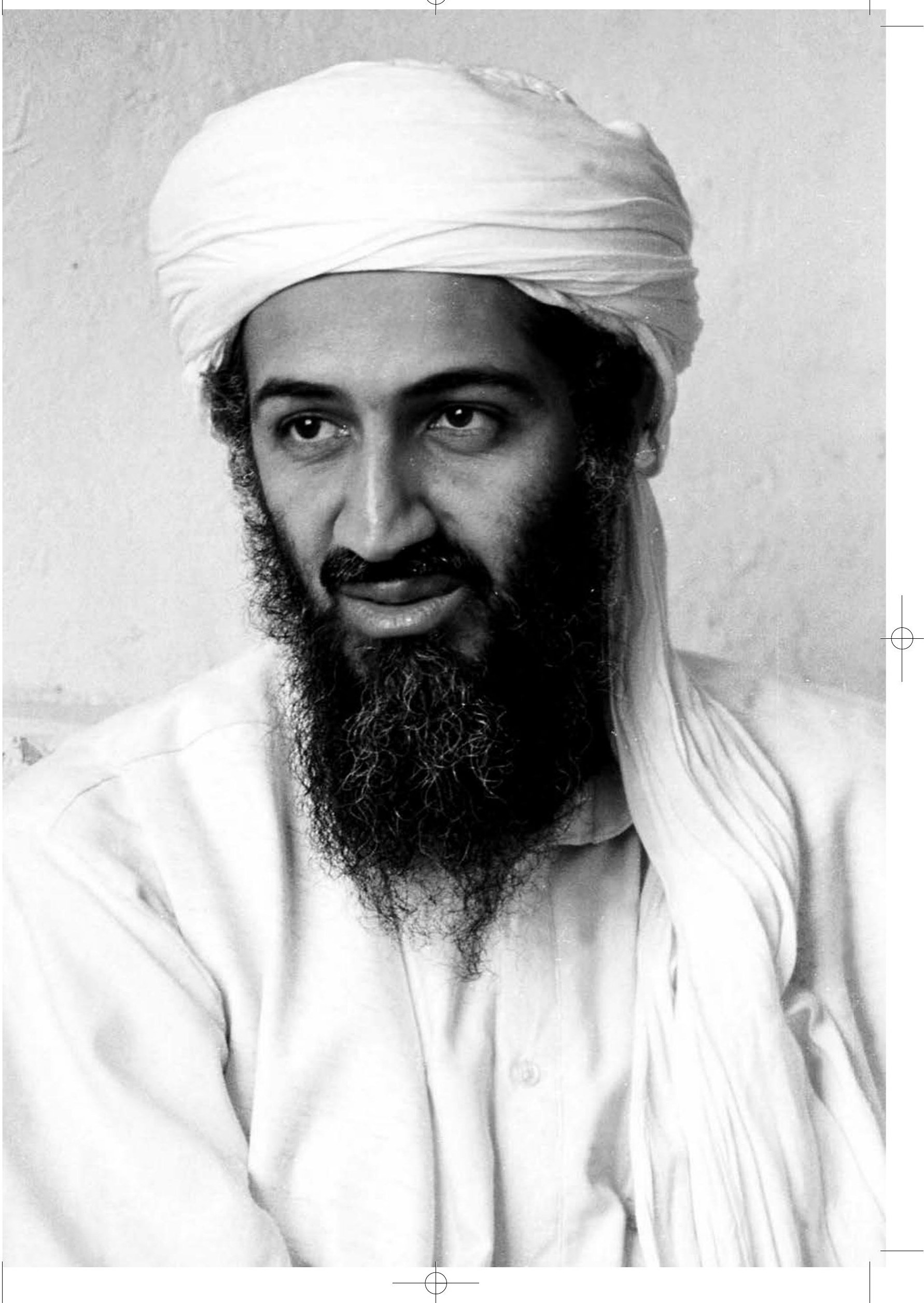


likegyldighet overfor dem. I et av de siste og mest kjente sitatene spissformulerer han sitt budskap til sine motstandere slik:

Dere har forsøkt å hindre oss $i$ à leve et verdig liv, men dere kan ikke hindre oss $i$ å dø en verdig $d \varnothing d{ }^{16}$

Bin Laden fremhever også stadig at kampen går fremover og refererer ofte til tidligere aksjoner for å styrke motstands- og kampviljen. De handlingene bin Laden oftest refererer til, er trolig de han anser for å være de viktigste: mujahidin sin seier $\mathrm{i}$ Afghanistan i I989 og angrepet på verdens handelsbygning i New York II. september 200I. I en kunngjøring fra januar 2006 sier han for eksempel:

Vi holdt ut $i$ ti år med enkle våpen $i$ krigen mot Sovjetunionen. Vi slet dem ut økonomisk inntil det, takket voere Gud, ikke ble annet tilbake av dem enn minner. ${ }^{17}$

\section{Bin Laden hater Vestens synder}

Mange forbinder rett nok bin Laden med en spesiell form for radikal islam. Som sagt er det ikke først og fremst for sin religiøse innsikt han tekkes de langt fleste av sine tilhørere, men snarere for sine politiske evner. I talene fremstår han dessuten sjelden som særlig militant og snakker lite om sin religiøse retning. Sentrale temaer i tekstene er derimot de lidelsene og ydmykelsene muslimene opplever, og disse opplevelsene kobles opp mot Vesten i en appell til folks følelser og fornuft. Bin Laden taler med andre ord når det foreligger en retorisk situasjon, en situasjon som krever at noen sier noe.

I retorikken benyttes den greske termen kairos om det rette øyeblikket til å si noe, og kairos er også et uttrykk for de retoriske muligheter som finnes i en bestemt situasjon. Når det rette øyeblikket er inne, kan taleren med suksess frembringe budskapet sitt. Som sådan er kairos en situasjonell anledning som gir talere mulighet til å fremme en sak. ${ }^{\mathrm{I}}$ Et eksempel på en slik situasjonell anledning er invasjonen av Irak, for dette er et tema som vekker sterke følelser hos folk. I en kunngjøring fra 2004 sier bin Laden:

Saddam er riktignok en tyv og en frafallen, men løsningen kan aldri vore å overføre Irak fra den lokale tyven til den internasjonale tyven. Det å legge til rette for at den vantro og hjelperne hans kan ta muslimenes jord og få kontroll over dem, er en av de ting som er $i$ strid med islam. ${ }^{19}$

En viktig kilde til forståelsen av bin Ladens veltalenhet ligger i den politiske konteksten ordene blir ytret i: de mange krisene i den muslimske verden, som ofte er hovedtemaet for talene hans. Det er ofte i krisetider at de virkelig karismatiske lederne dukker opp, og kriser kan være et kraftfullt virkemiddel for å oppnå innflytelse fordi de er truende og angst-skapende. ${ }^{20}$ En leder som er i stand til å skape en felles forståelse av hva krisen i for eksempel Irak består av en felles oppfatning av hva det er som foregår, hvorfor krisen er oppstått og hva som kan gjøres for å motvirke den, vil kunne redusere folks engstelse og trusselopplevelse og på denne måte få stor oppslutning blant folk. Det er dette bin Laden i stor grad forsøker å gjøre.

\section{Slaktehus i Halabja og Falluja}

I et brev fra 2004 spør bin Laden retorisk hva som er forskjellen mellom Saddams 
tyranniske slaktehus i Halabja og Bush sitt slaktehus i Falluja, og han fortsetter:

Om Saddam, i den stinkende nasjonalismens navn, har drept tusener av våre kurdiske brødre, må Gud se $i$ nåde til dem, så har vår tids farao i Falluja alene også drept tusener, og såret og lemlestet mangfoldig flere, i tillegg til å skremme opp hundretusener og drive dem på flukt. Alt dette $i$ det blodtørstige sionistiske korstogets navn. ${ }^{21}$

Han sier videre at det ikke er mulig å forklare disse angrepene på noen annen måte enn at det dreier seg om en omfattende krig mot islam og islams folk - en krig som er oppstått for å bekjempe islam og gjøre muslimenes land til et kristent område. I følgende sitat referer "han" til president George W. Bush:

Har han ikke sagt at Irak er et av landene $i$ ondskapens akse? Denne beskrivelsen betyr $i$ kristen sammenheng at vi er vantro og ikke har noen verdi, og det er det som forklarer at de okkuperer vårt land, dreper oss og sender hundrevis av soldater til fengslene $i \mathrm{Abu}$ Ghraib, Guantanàmo og andre steder hvor avskyelige handlinger som ryster all menneskelig følelse blir begått mot våre noere brødre.22

Ifølge bin Laden dreier det seg altså om en angrepskrig, og jihad er måten han mener muslimene skal forsvare seg på:

Muslimer! Den som ikke er $i$ stand til a føre jihad med sitt liv, bør ikke voere gnien ved a unnlate å føre jihad med sine penger, sin penn og sin tunge. ${ }^{23}$

Ved å forsøke å skape en felles forståelse av situasjonen i Irak søker bin Laden økt inn- flytelse og makt, og på den måten kan retorikken hans virke samlende. Han befester sin egen ideologi og makt gjennom en oppslutning rundt sitt verdenssyn og en respons på krisen i form av jihad, slik han anbefaler i sine tekster.

\section{Bin Ladens stil}

Bin Laden fremstilles nå som en mektig skikkelse der avstanden til hans publikum er stor, en avstand som blant annet uttrykkes gjennom eksklusive klær og en elegant talestil. Visuelt fremstilles han som en leder for muslimene, som når han blir plassert i forgrunnen av et kart fra Midtøsten påtegnet det islamske flagget. Hans verbale maktutøvelse kommer til uttrykk gjennom de retoriske formene han benytter. Han leser opp talene sine, og benytter det formelle språket som er felles for de arabisktalende og i stor grad forbeholdt dem med høyere utdanning, og ikke dialekt som er hver manns språk. Bin Laden er svært nøye i sin språkføring og har trolig alltid vært opptatt av å snakke på et mest mulig korrekt arabisk.

Abdel Bari Atwan, al-Qaida-ekspert og sjefsredaktør for den London-baserte arabiske avisen al-Quds al-arabi, ${ }^{24}$ berømmer bin Ladens ferdigheter i arabisk, og også han forteller noe om hvor sentralt språket er $\mathrm{i}$ forhold til bin Ladens troverdighet. Atwan fikk nemlig ikke lov til å ta opp sitt intervju med bin Laden på lydbånd. Årsaken til dette var at al-Qaida ikke kunne stole på ham, for i fall bin Laden skulle gjøre en grammatisk feil, så kunne det kanskje bli brukt mot ham senere. Dette er trolig også noe av bakgrunnen for at bin Laden alltid leser opp talene sine og ikke snakker fritt.

Bin Laden markerer imidlertid ikke bare stor avstand til sitt publikum gjennom 
elevert språkbruk og elegante klær. Talene hans bærer også preg av en nærhet til publikummet, som for det første uttrykkes gjennom temaene han omtaler. For det andre uttrykkes nærheten til publikummet

Bin Laden uttaler seg ofte på vegne av hele det muslimske samfunnet ved a bruke pronomenene "vi" og "oss".

gjennom bruk av pronomenene "vi" og "oss". Han uttaler seg med andre ord ofte på vegne av hele det muslimske samfunnet der han inkluderer seg selv og alle andre muslimer i et "vi" eller "oss". I forbindelse med karikaturtegningene av Profeten Muhammad sier bin Laden blant annet:

Når det gjelder disse som sjikanerer vår profet, som krenket ham med disse tegningene, så krever vi at deres styresmakter utlever dem til oss slik at vi kan dømme dem etter Guds sharia. ${ }^{25}$

Denne formen for pronomenbruk er et viktig trekk ved bin Ladens retorikk, der han inkluderer seg selv i et stort vi, som refererer til hele det internasjonale muslimske samfunnet. I sin språkbruk fremstår han derfor med langt flere tilhengere og meningsfeller enn det han egentlig har.

Gjennom analyser av bin Ladens tale og fremtreden blir det tydelig at han på den ene siden fremstiller seg selv som en del av folket gjennom den utbredte bruken av pronomenet "vi" og gjennom temaene han omtaler. På den andre siden fremstiller han seg selv som en leder med stor avstand til vanlige folk gjennom elevert språkbruk og elegant klesdrakt. På den måten kan det være han tilfredsstiller mange menneskers forventninger til en leder, en som på samme tid både er en av dem og representerer en autoritet. Han skiller seg fra vanlige folk ved sin språklige stil og materielle fremtreden, men deler vanlige folks opplevelser, lidelser og frustrasjoner gjennom temaene han berører i talene sine. Han ser ut til å ha en egen evne til å tilpasse seg mange tilhørere gjennom sin massekommunikasjon, for han forenkler kompliserte politiske forhold og trekker ut de årsakene til de ulike krisene som ikke bare passer best inn i hans verdensbilde, men som også er gjenkjennelige situasjonsbeskrivelser for mange andre. Bin Laden og alZawahiri har dessuten alltid vært svært bevisste sine opptredener. Al-Zawahiri har sagt at "vi må vinne folks respekt, tillit og hengivenhet. Folk kommer ikke til å holde av oss med mindre de føler at vi er glade $i$ dem, at vi bryr oss om dem og at vi er villige til å forsvare dem.. ${ }^{26}$ Disse ordene utgjør i stor grad essensen i mange av bin Laden sine taler, og de er nok også mye av forklaringen på den medieoppmerksomheten han ofte tildeles $\mathrm{i}$ forbindelse med talene sine.

\section{Bin Ladens slagkraft}

All medieoppmerksomheten tyder på at Osama bin Laden fremdeles er en mektig mann det er interesse for. I vestlige medier dominerer bildet av ham som verdens mest ettersøkte terrorist. I panarabiske medier er bildet mer variert, slik denne artikkelens eksempel fra al-Jazeera viser, der bin Laden fremstilles som en helt.

Denne fremstillingen kan virke ube- 
gripelig for dem som hovedsakelig forbinder ham med terrorisme. Jeg har derfor forsøkt å kaste lys over bin Ladens popularitet gjennom analyser fra hans tekster, og det mest iøynefallende ved bin Ladens retorikk er at han ser ut til å ønske å påvirke mange ulike mennesker. Han taler derfor til et bredt publikum, og han velger ofte en tematikk det er bred enighet om. I tillegg til tematikk har jeg her også satt fokus på andre retoriske ressurser bin Laden utnytter, som klesstil, språkvalg og fiendebilder. Bin Ladens språkvalg er sentralt for måten han bygger sin troverdighet på, for varieteten han benytter forbindes ikke bare med den ypperste veltalenhet, men det er også det hellige språket i Koranen. Språkvalg, klesstil og tematikk er viktig for bin Ladens troverdighet og slagkraft, men det mest interessante ved tekstene hans synes å være den kreativiteten han fremviser gjennom sine mer subtile uttrykksformer. Denne kreativiteten kommer særlig til uttrykk når han utnytter retoriske ressurser som satire og kjente historiske symboler i sine fiendebilder.

Tekstene til bin Laden har imidlertid i liten grad vært studert, og med nye og mer omfattende analyser kan bildet av tekstene endre seg. Ikke minst endrer tekstene selv stadig karakter ved å ta i bruk ny teknologi.

\section{$\cdot f \cdot$}

I Atwan, Abdel Bari: «The secret history of al-Qa'ida». GB: Saqi Books, 2006:3I.

2 Som referert hos Bergen, Peter: «The Osama bin Laden I Know". New York: Free Press, 2006:I69.

3 Lawrence, Bruce. (red.): «Budskap til verden: Osama bin Ladens brev og taler". Oslo: L.S.P forlag, 2007:447.

4 www.vg.no Gir ut bin Ladens taler på norsk, 2007. Lastet ned I5.I2.07.

5 www.al-jazeera.net, 2006. Lastet ned I5.I2.07
6 Kjeldsen, Jens E. “Øjets Frygt og ærefrygt”, I Rhetorica Scandinavica nr. 42, 2007.

7 Kjeldsen.

8 www.boston.com 2004. Bin Laden's words echo US politics. Lastet ned 5.10.06

9 www.boston.com

Io Ali, Tariq: «Fundamentalismens kamp, korstog, hellig krig og det moderne". Oslo:J.W. Cappelens Forlag, 2005:23.

II Nilsen, Anne Birgitta: “Osama bin Ladens skjulte slagkraft”, i Norsk Medietidsskrift nr. 4, 2007.

I2 Lawrence: 423

I3 www.whitehouse.gov Address to a Joint Session of Congress and the American People, sept. 200I. Lastet ned I5.I2.07

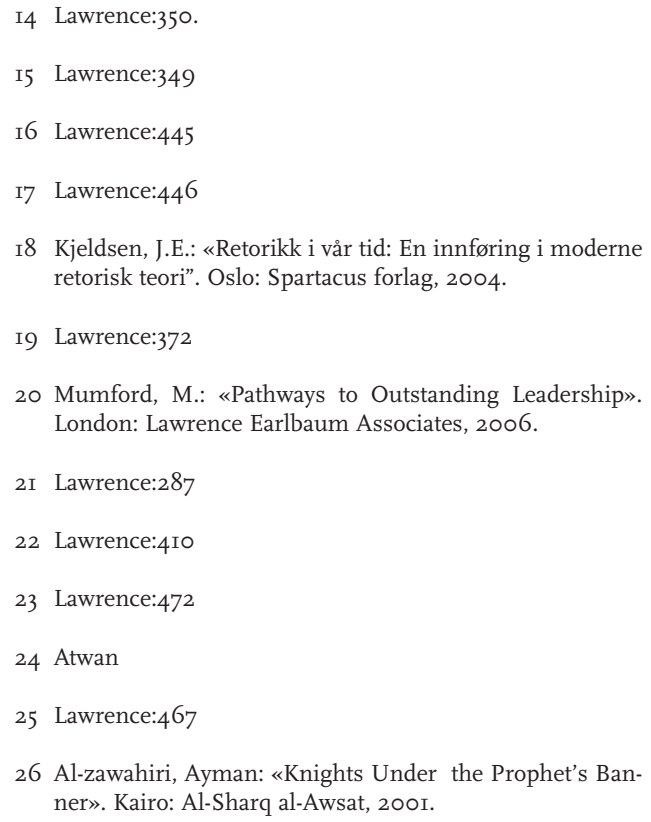

